\title{
CHOUMIRYOU TRADISIONAL PADA MASAKAN JEPANG MODERN
}

\author{
Sriwahyu Istana Trahutami \\ Universitas Diponegoro \\ utami_undip@yahoo.com
}

\begin{abstract}
Abstrak
Artikel ini adalah kajian pustaka yang membahas tentang bagaimana orang Jepang menggunakan bumbu tradisional pada masakan Jepang. Bumbu tradisional atau choumiryou yang menjadi fokus penelitian dibatasi pada pada bumbu dasar yang terdiri dari miso, shoyu, dan dashi yang dihasilkan dari konbu dan katsuobushi. Data dikumpulkan melalui dokumentasi terhadap artikel dan buku yang berkaitan dengan bumbu tradisional Jepang. Tujuan penulisan untuk mengetahui jenis dan cara pembuatan choumiryo yang menjadi ciri khas masakan Jepang, serta bagaimana bumbu dasar tersebut digunakan pada sebuah masakan. Metode yang digunakan adalah deskriptif kualitatif untuk mendapatkan gambaran secara utuh tentang jenis dan proses pembuatan bumbu dasar tesebut. Dari hasil analisis diketahui bahwa bumbu dasar pada masakan Jepang bukan berasal dari rempah-rempah seperti yang digunakan pada masakan Asia Tenggara. Sebagian besar Choumiryo berasal dari proses peragian (fermentasi) kedelai, kacang-kacangan, gandum atau beras, serta berasal dari ikan. Proses pembuatannya pun rumit memerlukan waktu berbulan-bulan. Melalui proses tersebut dihasilkan rasa yang lezat sekaligus merupakan bahan pengawet makanan alami.
\end{abstract}

Kata kunci: masakan Jepang; choumiryo; bumbu tradisional

\begin{abstract}
This article discusses how Japanese people use traditional herbs in Japanese cuisine. Traditional spices or choumiryou which are the focus of research are limited to basic spices consisting of miso, shoyu, and dashi produced from konbu and katsuobushi. Data is collected through documentation of articles and books relating to traditional Japanese spices. The purpose of writing is to find out the type and method of making choumiryo that characterizes Japanese cuisine, as well as how the basic ingredients are used in a dish. The method used is descriptive qualitative to get a complete type and process of making the basic seasoning. From the analysis results it is known that the basic seasoning in Japanese cuisine is not derived from spices as used in Southeast Asian cuisine. Most of Choumiryo comes from the fermentation process of soybeans, beans, wheat or rice, and comes from fish. The manufacturing process is also complex and takes months. Through this process a delicious taste is produced as well as a natural food preservative.
\end{abstract}

Keywords : Japanese cuisine; choumiryo; traditional herbs

\section{PENDAHULUAN}

Penduduk Jepang mempunyai angka harapan hidup tertinggi di dunia. Rata-rata usia lelaki adalah 78 tahun, sedangkan wanita mencapai usia 85 tahun. Data statistik kementerian kependudukan di Jepang mengatakan bahwa jumlah orang yang berumur di atas 100 tahun meningkat menjadi 20.561 orang di tahun 2003. 
Kiryoku, Volume 3 No 32019

e-ISSN: 2581-0960 p-ISSN: 2599-0497

Tersedia online di http://ejournal.undip.ac.id/index.php/kiryoku

Sedangkan tahun sebelumnya mencapai 20.000 orang. Hal ini menunjukkan bahwa angka harapan hidup semakin meningkat setiap tahunnya.

Salah satu alasan mengapa harapan hidup di Jepang sangat Panjang dibandingkan dengan negara-negara lain adalah faktor makanan. Makanan tradisional pada dasarnya adalah resep agar orang panjang umur. Tidak dapat dipungkiri bahwa makanan yang disantap selama berpuluh tahun inilah yang merupakan faktor penting yang menjadi rahasia umur panjang. Makanan tradisional Jepang yang merupakan tradisi warisan leluhur dan budaya turun-temurun dari generasi ke generasi berikutnya menjadi hal yang ingin diketahui banyak orang bukan hanya orang Jepang. Makanan Jepang tradisional baik untuk kesehatan, mempunyai kandungan nutrisi yang bagus yang memperlambat penuaan sel. Berkat makanan proses penuaan orang Jepang lebih lambat dibandingkan dengan penduduk lain di muka bumi. Sudah lazim kita lihat bahwa orang Jepang kelihatan lebih muda dan lebih enerjik daripada usia sebenarnya.

Masakan tidak akan enak tanpa adanya bumbu yang pas. Bumbu akan memberikan kelezatan rasa juga memberikan warna pada masakan. Seperti negara lainnya Jepang juga mempunyai bumbu khusus, bumbu tradisional yang dipakai untuk masakan Jepang, mempunyai citarasa khas tersendiri yang akan membuat masakan Jepang juga mempunyai rasa kelezatan khas. Ada 5 bumbu yang dipakai pada masakan Jepang. Penyebutan bumbu ini diurutkan sesuai urutan huruf jepang Hiragana yaitu sa, shi, su, se, dan so. Sa adalah sato atau gula, shi adalah shio atau garam, su adalah cuka masak, se adalah seuyu yang merupakan asal kata shoyu atau kecap asin, dan so adalah miso. Choumiryono sashisuseso ini merpakan jenis bumbu yang lazim digunakan pada masakan Jepang sekaligus menunjukkan urutan memasukkan bumbu tersebut ke dalam masakan. Choumiryo dalam Bahasa Jepang artinya bumbu masakan.

Masakan Jepang menggunakan banyak bumbu. Teknik pembuatan bumbu tradisional ini sangat mengandalkan kondisi iklim yang bervariasi juga berasal dari sumber bahan yang sudah tersedia di alam Jepang. Bumbu mempunyai tradisi sejarah yang panjang dan hingga sekarang masih dipertahankan cara-cara pembuatannya secara tradisional.

Tujuan penulisan artikel ini adalah untuk mendeskripsikan secara utuh tentang apa saja jenis choumiryou tradisional pada masakan Jepang serta teknik pembuatan bumbu dasar tersebut. Selain itu melalui deskripsi tentang bumbu dasar yang berfokus pada miso, shoyu, dan dashi dapat diperoleh gambaran tentang karakteristik masakan rumahan keseharian orang Jepang.

Kajian tentang bumbu masakan Jepang sudah banyak dilakukan, rose (2011) dan photo (2010) pada artikel jurnalnya membahas tentang kebiasaan makan imigran jepang dan china hasil penelitian menunjukkan bahwa pekerja jepang mengkonsumsi makanan dengan kombinasi gaya antara asia dan barat sementara orang china sangat tergantung pada makanan tradisional mereka. Namun kebanyakan merupakan pembahasan dari bumbu dengan akronim sashisuseso, yaitu sato, shio, su, shoyu, dan miso seperti pada penelitian

Selain itu penelitian tentang bumbu masakan juga banyak dikaitkan dengan kesehatan. Junko Suzuki(2001), meneliti tentang perubahan pola pemakaian bumbu masakan serta bagaimana kandungan bumbu masak yang digunakan di kantin sekolah dan hubungannya dengan kesehatan.

\section{METODE}

Metode yang digunakan pada penelitian ini adalah deskriptif kualitatif yaitu metode riset yang bersifat deskriptif, menggunakan acuan data dan didukung 
oleh teori yang sudah ada. Data non numerik penulis kumpulkan dari buku, majalah dan artikel tentang shoku bunka di Jepang (budaya makanan) terutama yang berhubungan dengan choumiryou pada masakan Jepang. Dengan menganalisis data dari pustaka tersebut diharapkan melalui artikel ini dapat memberikan gambaran secara utuh tentang choumiryou tradisional yang hingga dewasa ini mempunyai fungsi untuk memberikan kelezatan sekaligus merupakan pemberi ciri khas masakan Jepang.

Adapun tahapan pada penelitian ini adalah, mengangkat permasalahan yang berhubungan dengan jenis choumiryo tradisional apa yang hingga sekarang masih tetap digunakan di berbagai masakan Jepang yang menjadi ciri khas atau identitas rasa masakan. Permasalahan diangkat dalam rumusan masalah dengan memunculkan pertanyaan-pertanyaan. Langkah selanjutnya adalah mengumpulkan data yang relevan dengan tema choumiryou, dan shoku bunka dari berbagai pustaka. Kemudian melakukan analisis data sehingga dapat menjawab pertanyaan-pertanyaan yang sudah disusun dalam rumusan masalah. Deskripsi jenis bumbu tradisional dengan memberikan gambaran tentang miso, shouyu, dashi, konbu serta katsuobushi. Dari data berupa resep masakan Jepang terlihat bahwa bahan masakan selalu diutamakan bahan yang segar, sedangkan bumbu dan kaldu berfungsi untuk menonjolkan kelezatan bahan tersebut. Sebagian besar bumbu masakan Jepang merupakan hasil olahan ikan, ganggang laut, rumput laut yang diproses lama dengan cara fermentasi atau dikeringkan dengan bantuan keadaan iklim daerah tersebut. Misalnya miso yang terkenal kelezatannya adalah miso yang berasal dari propinsi Nagano. Rasa enak miso Nagano sangat dipengaruhi oleh kondisi air dan udara Nagano yang sangat mendukung sebagai daerah pembuat miso. Nagano terletak di dataran tinggi dan dikelilingi pegunungan sehingga mempunyai musim dingin yang dingin dan musim panas yang hangat yang cocok untuk proses fermentasi kedelai lokal sebagai bahan pembuatan pasta miso. Propinsi Chiba dikenal dengan shoyu atau kecap asinnya yang terenak. Sedangkan katsuobushi, semacam abon ikan cakalang banyak diproduksi di daerah Makurazaki, di propinsi Kagoshima.

\section{HASIL DAN PEMBAHASAN}

Makanan Jepang dasar adalah apa yang disebut ichi ju san sai yaitu 3 macam lauk yang dimakan dengan sup miso dan nasi. 3 lauk tersebut merupakan lauk utama dan 2 macam lauk pelengkap. Ichi ju san sai ini dikembangkan oleh kaum militer Jepang pada jaman Muromachi abad 14 hingga abad 16 yang masih terus dijadikan standard hingga sekarang. Lauk utama adalah protein tinggi bukan jenis sayuran. Biasa digunakan ikan sebagai bahan utama baik disantap mentah maupun dimasak melalui merebus, memanggang atau yang lainnya. Salah satu lauk pelengkap biasanya direbus dan dibumbui, sebagai contoh adalah kentang, wortel, lobak, ganggang laut atau konbu. Lauk pelengkap lainnya mungkin berupa natto (kacang kedelai fermentasi), tahu, kacang-kacangan yang dimasak, sayuran rebus yang direndam kaldu dan diberi bumbu kecap asin atau cuka manis seperti berbagai acar yang paling umum adalah acar apricot atau umeboshi.

Orang Jepang sangat menyukai makanan yang bahannya diperoleh di musim tersebut sehingga kesegaran dan rasa lezatnya terjaga.Ikan maupun sayuran akan dipilih yang sedang panen pada musim tersebut. Kandungan nutrisi pun sangat diperhatikan pada pola makan ichi ju san sai. Nasi mengandung lechitin yang mampu meningkatkan kerja otak, oligosaccharide yang menyegarkan usus serta asam gamma amino butyric yang dapat menstabilkan tekanan darah. Kedelai dan olahannya termasuk pasta miso yang 
merupakan bumbu sup, tahu, kacang kedelai rebus maupun natto mengandung protein 35\% hampir menyerupai daging. Selain itu juga mengandung polyphenol dan isoflavone yang bermanfaat untuk hormone wanita, mencegah kerapuhan tulang dan meningkatkan massa tulang, Kacang kedelai juga memperlambat penuaan sel. Kedelai fermentasi pada mengandung asam amino yang tinggi yang meningkatkan umur panjang selama berabad-abad lalu. Ikan mengandung DHA untuk meningkatkan kecerdasan juga mengandung EPA untuk meningkatkan sirkulasi darah. Sayuran dan tahu serta ganggang laut semua merupakan sumber vitamin, mineral, serat, dan antioksidan yang sangat diperlukan tubuh. Selain pola makanan dasar ini kebiasaan orang Jepang minum teh hijau ternyata juga sangat bermanfaat untuk hidup Panjang umur. Catechin kandungan yang terdapat di teh hijau dapat mencegah oksidasi sel, kanker juga berbagai penyakit akibat pola gaya hidup modern. Selain bahan masakan penggunaan bumbu tradisional juga memberikan rasa lezat sekaligus menambah kandungan nutrisi pada bahan masakan. Hal ini karena sebagian besar bumbu masakan Jepang juga terbuat dari bahan bernutrisi tinggi yaitu kedelai dan hasil ikan yang diolah melalui proses permentasi, pengeringan, perebusan dan proses lain yang semuanya memerlukan waktu berbulan-bulan untuk mendapatkan rasa yang optimal.

\section{JENIS DAN PROSES PEMBUATAN CHOUMIRYO TRADISIONAL}

Jenis bumbu tradisional yang akan dipaparkan pada artikel ini adalah shoyu atau kecap asin Jepang, miso yaitu bumbu dasar pembuatan sup yang berupa pasta kacang kedelai fermentasi, konbu atau ganggang laut, dashi atau kaldu yang merupakan kunci masakan Jepang. Dashi terbuat dari ikan, jamur shiitake, ikan kering maupun dari ganggang laut. Bumbu lain yang tak kalah pentingnya adalah katsuo bushi atau abon ikan bonito atau ikan cakalang.

\section{1) Miso}

Miso adalah pasta bumbu yang terbuat dari kedelai, yang merupakan bumbu wajib untuk masakan sup Jepang, seperti shoyu.Pada setiap masakan rumahan di Jepang sup miso atau misoshiru adalah menu keseharian yang selalu ada dan merupakan pendukung utama untuk bersantap. Sup ini dibuat dengan cara kaldu yang sudah jadi, diberikan tambahan tahu, wakame, atau bahan lain, kemudian ditambahkan pasta miso ke dalamnya. Miso berfungsi untuk menghilangkan bau amis ikan atau daging serta menimbulkan rasa enak pada bahan masakan, sehingga miso ini digunakan pada masakan yang direbus menggunakan panci di atas meja atau masakan yang direbus lama. Miso terbuat dari kedelai yang dikukus, dihancurkan, dan digarami, kemudian dicampur dengan jamur koji sebagai bahan fermentasinya. Jamur koji dicampurkan pada kedelai, beras, gandum, atau bijibijian lainnya, kemudian dibiarkan selama berbulan-bulan bahkan setahun untuk proses fermentasi. Teknik pembuatan miso berasal dari Cina yang sudah dikenal lebih dari 1300 tahun yang lalu. Tiga jenis utama miso yang ada di Jepang adalah :

a. Miso kome (campuran jamur koji dan beras)

b. Miso mugi (campuran jamur koji dan gandum mugi)

c. Miso mame (campuran jamur koji dan kacang)

Miso kome merupakan miso yang paling banyak digunakan, mempunyai rasa dan warna yang agak berlainan di tiap daerah. Masyarakat yang tinggal di daerah dingin cenderung menyukai miso kome yang berwarna lebih gelap dengan kandungan garam yang lebih banyak, sedangkan Jepang wilayah selatan yang bersuhu hangat masyarakatnya cenderung mengkonsumsi miso yang lebih muda warnanya dan rasanya pun lebih ringan.

\section{2) Shoyu}


Shoyu atau kecap asin juga bumbu yang harus ada di hampir semua masakan. Kecap asin juga terbuat dari kedelai. Kedelai, gandum, dan garam dimasukkan ke dalam air. Kemudian ditambahkan air asin dan jamur koji, dibuat sampai menjadi bubur atau moromi, selanjutnya akan dibiarkan beberapa bulan. Setelah proses fermentasi selesai bubur diperas, air yang dihasilkan direbus untuk menghilangkan bakteri. Air perasan tersebut adalah shoyu. Ada tiga jenis shoyu yang ada di pasaran, yaitu :

a. Koi kuchi yaitu kecap asin dengan warna pekat dan rasa kuat. Jenis ini adalah jenis yang paling populer.

b. Usu kuchi yaitu kecap asin dengan warna muda dan rasa lebih ringan. Tidak mengubah rasa masakan.

c. Tamari yaitu kecap asin dengan kandungan kacang kedelai yang lebih tinggi dan sedikit kandungan garam dibandingkan dengan jenis shoyu lain.

\section{3) Dashi}

Dashi atau kaldu juga merupakan kunci utama masakan Jepang. Dashi terbuat dari kaldu ikan bonito kering, ikan kecil kering, ganggang laut konbu, jamur shiitake kering atau sejenisnya. Bahan kaldu ini dimasak lama untuk mengeluarkan rasa kelezatannya. Kaldu dasar yang utama adalah dashi yang terbuat dari ganggang laut konbu dan dashi yang terbuat dari ikan bonito kering.

\section{a. Konbu Dashi}

Konbu atau ganggang laut sudah mempunyai rasa asli yang lezat. Setelah ganggang laut dipanen selanjutnya akan dikeringkan, biasanya hanya mengandalkan sinar matahari untuk proses pengeringannya. Tiga hari. Proses ini memerlukan waktu dua hingga Untuk membuat kaldu konbu, potong konbu sesuai ukuran yang diinginkan, masukkan ke dalam panci yang berisi air, kemudian panaskan hingga mendidih. Setelah mendidih keluarkan konbu. Kaldu yang dihasilkan oleh konbu adalah kaldu yang bening, rasanya ringan sehingga cocok untuk masakan sup suimono atau resep lain yang memerlukan kaldu yang bening.

\section{b. Katsuo Dashi}

Kaldu katsuo berasal dari ikan bonito kering atau katsuo bushi atau ikan cakalang. Ikan kering ini disebut sebagai makanan terkeras di dunia, karena menyerupai kayu. Ikan bonito kering diserut untuk dibuat kaldu. Masukkan serutan ikan tadi ke dalam air yang sudah mendidih atau hampir mendidih, matikan api, diamkan sebentar kemudian angkat. Kaldu dari rebusan pertama ikan bonito disebut ichi ban dashi (kaldu nomer satu). Serutan ikan pada kaldu pertama dapat digunakan kembali untuk menghasilkan $n i$ ban dashi (kaldu nomer dua).

Katsuo bushi berasal dari ikan bonito yang dipotong potong besar untuk diambil dagingnya setelah dicuci. Selanjutnya potongan ikan direbus pada suhu sekitar 90 derajat agar ikan tidak retak. Setelah proses perebusan ikan dikeluarkan dari air, tulang juga dikeluarkan, kemudian dipotong dengan ukuran yang lebih kecil. Potongan ikan selanjutnya diasap dengan api kayu yang menyala kecil, setelah itu didinginkan pada suhu ruang, kemudian diasap lagi, didinginkan kembali berulang hingga beberapa kali. Produk yang dihasilkan adalah arabushi. Arabushi diserut, dibungkus dan selanjutnya bisa dikonsumsi. Namun untuk menghasilkan kaldu yang asli masih memerlukan beberapa tahapan lagi. Arabushi harus dijemur lagi, bagian atas dan bagian luar arabushi diserut, menghasilkan hadakabushi. Hadaka bushi kering akan disimpan di ruangan yang dikontrol suhu dan kelembabannya sampai tumbuh jamur aspergillus di permukaannya. Proses berikutnya adalah dijemur kembali, jamur dihilangkan, disimpan kembali di ruang pengawetan, berulang kali hingga 4 kali sampai menghasilkan produk honbushi 
asli. Jamur akan mengeluarkan air pada ikan secara alami dan perlahan-lahan sehingga ikan menjadi kering dan keras, menambah kandungan asam amino sekaligus menambah rasa lezat pada hasil akhir masakan.

Pada masa sekarang ini orang tidak akan repot lagi untuk membuat bumbu dasar masakan Jepang yang sangat Panjang pada proses pembuatannya. Mereka lebih menyukai bumbu dasar yang sudah siap saji atau instan. Namun demikian perusahan-perusahaan terkenal produsen bumbu masakan masih banyak yang melestarikan pembuatan bumbu ini secara tradisional untuk menghasilkan umami (kelezatan) asli.

Selain bumbu dasar yang telah diuraikan di atas, masih ada beberapa lagi choumiryo tradisional yang sering digunakan pada masakan Jepang, seperti arak sake, cuka dan mirin (sake manis). Mirin mempunyai rasa yang manis, biasanya digunakan untuk memberikan keseimbangan rasa asin shoyu sehingga didapatkan rasa gurih. Juga digunakan untuk mengurangi rasa asam pada cuka. Pada masakan Jepang, bumbu dengan rasa tajam dihindari untuk menjaga rasa asli bahan masakan yang diolah. Bumbu lain yang digunakan adalah yang berasa atau beraroma lembut, seperti kinome (aromatic springs) dari pohon sansho, yuzu (citrun), wasabi (Japanese horseradish), jahe, myouga, dan biji sansho kering yang dihaluskan.

\section{SIMPULAN}

Salah satu sebab mengapa orang Jepang berumur panjang adalah karena pola makannya. Sejak jaman dahulu nenek moyangnya secara tradisional mengkonsumsi makanan yang bergizi dan berimbang. Dari ajaran Budha, masyarakat Jepang sejak dahulu tidak pernah mengkonsumsi daging merah, sehingga konsumsi utama mereka adalah nasi, bermacam jenis ikan, dan sayuran maupun umbi-umbian dan kacang-kacangan. Orang
Jepang juga mempunyai kebiasaan memakan ikan, sayur dan buah yang dipanen pada musim tersebut misalnya, rebung pada musim semi, jeruk di musim dingin, ikan sanma dan jamur matsutake di musim gugur, Hasil sayur maupun ikan yang dipanen pada saat itu menurut mereka merupakan hasil terbaik dengan kandungan gizi paling bagus dibandingkan pada musim lainnya.

Bukan hanya bahan dasar masakan yang berkualitas bagus, bumbu masakan tradisional Jepang biasanya terdiri dari bumbu yang merupakan produk yang berasal dari ikan, dan kedelai, beras yang mengalami proses peragian atau fermentasi. Proses yang panjang hingga berbulan-bulan dilakukan untuk mendapatkan rasa terbaik dari bumbu tersebut. Proses fermentasi kacang kedelai menghasilkan produk miso,dan berbagai jenis shoyu. Fermentasi dari beras menghasilkan cuka atau su, dan arak masak (sake yang digunakan untuk bumbu), mirin (arak manis). Proses rumit dan panjang ikan bonito menghasilkan katsuo bushi yang merupakan bumbu dasar untuk dashi yang digunakan untuk berbagai masakan. Demikian juga ganggang laut konbu diproses untuk menjadi bumbu dasar kaldu konbu. Masakan Jepang biasanya mempertahankan rasa asli dari bahan asalnya bahkan beberapa dimakan mentah seperti sushi dan sashimi. Bumbu seperti kecap asin dan miso hampir digunakan di semua masakan, bisa sebagai saus penyedap atau digunakan sebagai bumbu dasar sup atau masakan yang direbus.

\section{DAFTAR PUSTAKA}

Danandjaja, James (1997). Folklore Jepang: Dilihat dari Kacamata Indonesia. Jakarta: Pustaka Utama Grafiti

Junko TSUDZUKI and Keiko NAKASHIMA, (2001). Influence of Using "Sonota no Choumiryo" on 
Kiryoku, Volume 3 No 32019

e-ISSN: 2581-0960 p-ISSN: 2599-0497

Tersedia online di http://ejournal.undip.ac.id/index.php/kiryoku

the Amount of Salt lntake, 椙 山女学園大学研究論集 第 32 号 (自然科学篇)

Koentjaraningrat, (1992). Beberapa Pokok Antropologi Sosial. Jakarta:Dian Rakyat

Photo, Margherita. (2010). Food Law Under The Rising Sun. Berlin : Lexxion

Rahman, Fadli. (2016). .Jejak Rasa Nusantara. Jakarta: PT. Gramedia Utama

Sugimoto, Yoshio. 2014. An Intoduction to Japanese Society. Melbourne: Cambridge

Rujuan Internet

Https://cookien.com/seasoning (07/12) 